Siti Aisyah Youtefani

\title{
APLIKASI SISTEM DISKON PSIKOLOGIKAL DALAM STRATEGI PENETAPAN HARGA DITINJAU DARI HUKUM ISLAM (Studi di Carrefour Serang)
}

\begin{abstract}
Abstrak
Persaingan bisnis merupakan aktivitas ekonomi yang penting sebagai acuan untuk meningkatkan kualitas produksi. Banyak metode kontemporer yang digunakan para pelaku usaha untuk menghadapi persaingan. Teori mutakhir yang kini tengah diusung adalah neuromarketing yang faktanya bisa mempengaruhi psikologi konsumen sehingga dengan mudah tertarik untuk mengkonsumsi produk yang ditawarkan. Dengan cara mempengaruhi psikologi, ada pebisnis yang melakukan penipuan supaya dapat meraup keuntungan sebesar-besarnya. Contohnya dengan praktek diskon psikologikal yang dinaikkan harganya terlebih dahulu lalu kemudian didiskon. Umumnya praktek tersebut biasa terjadi di perusahan-perusahaan ritel besar. Oleh karena itu, penulis mencoba studi kasus di perusahaan Carrefour.

Ada tiga tujuan yang ingin dicapai mellaui penelitian ini. Pertama, untuk mengetahui kebijakan penetapan harga pada perusahaan Carrefour ditinjau dari sudut pandang Islam. Kedua, untuk mengetahui konsep neuromarketing dalam perspektif Islam, dan tujuan ketiga untuk mengetahui tinjauan hukum Islam terhadap diskon psikologikal.

Hasil studi lapangan dan studi pustaka diperoleh tiga kesimpulan sebagai berikut: Pertama, beberapa strategi yang diterapkan Carrefour dalam menjalankan bisnisnya ternyata ada yang sesuai dan ada yang tidak sesuai syari'at Islam. Terdapat aplikasi ghabn faahisy atau penipuan dalam prakteknya. Ghabn faahisy haram dalam Islam. Kedua, konsep neuromarketing tidak dilarang dalam Islam selama dilakukan dengan transparan dan jujur, karena asal dari mu'amalah adalah boleh. Ketiga, diskon psikologikal bisa juga diqiyaskan dengan odd pricing, yang dalam aplikasinya terdapat ghabn faahisy atau tadlis atau najasy atau tipuan yang hukum keharamannya sudah jelas.
\end{abstract}

Kata Kunci: Bisnis, ritel, diskon, psikologi.

\section{Pendahuluan}

Manusia pada dasarnya diciptakan sebagai makhluk zonepoliticon yang saling membutuhkan untuk saling melengkapi dan memerlukan interaksi dengan manusia lain. Interaksi yang merupakan perilaku untuk mengusahakan pemenuhan kebutuhan- 
kebutuhan hidup manusia disebut dengan kegiatan bisnis. Kegiatan bisnis adalah sangat penting. Tanpa adanya kegiatan bisnis maka kehidupan manusia tidaklah sempurna. Bisnis melayani kebutuhan manusia akan barang dan jasa, rohani dan jasmani. ${ }^{1}$

Kebutuhan manusia yang bersifat tidak terbatas dan keinginannya yang berkembang terus menerus membuat kegiatan bisnis semakin menjamur di sekitar masyarakat. Baik heterogenitas maupun homogenitas kegiatan-kegiatan bisnis yang sangat banyak menciptakan persaingan para pelaku usaha untuk menarik perhatian konsumen. Persaingan bisnis merupakan aktivitas ekonomi yang penting sebagai acuan untuk meningkatkan kualitas produksi, asal tetap sportif dan sesuai prosedur karena jika kegiatan bisnis merugikan banyak pihak disebabkan ketidakjujuran pelaku usaha, maka bisnis tersebut tidak boleh dijalankan.

Allah Swt. melarang manusia untuk berlaku curang dan menganjurkan untuk bertransaksi dengan jalan suka sama suka, seperti yang dijelaskan dalam surat AnNisa' ayat 29:

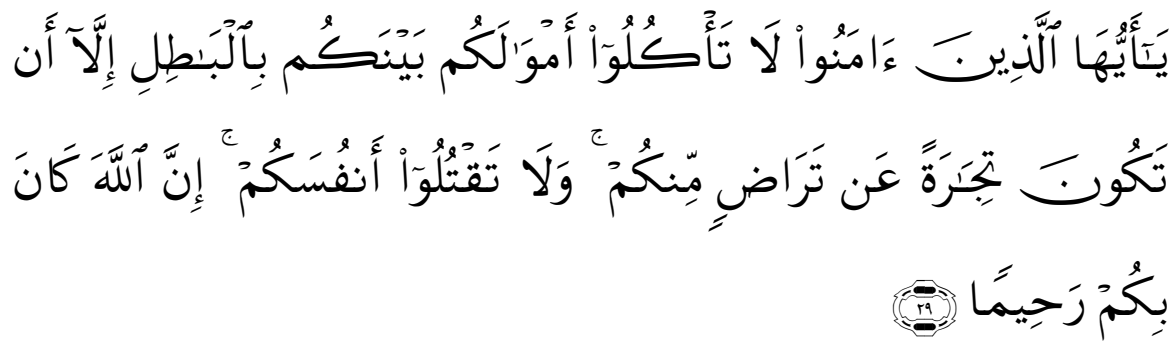

"Hai orang-orang yang beriman, janganlah kamu saling memakan harta sesamamu dengan jalan yang batil, kecuali dengan jalan perniagaan yang berlaku dengan suka sama-suka di antara kamu, dan janganlah kamu membunuh dirimu. Sesungguhnya Allah adalah Maha Penyayang kepadamu." (Q.S. An-Nisa': 29)

Oleh karena itu, setiap pelaku usaha harus selalu bersikap proaktif, berusaha untuk berkreasi, meningkatkan sumber daya, menciptakan inovasi dalam produk yang dihasilkan dan atau mengatur strategi usaha.

Di antara strategi usaha yang melayani secara langsung keinginan konsumen adalah strategi pemasaran. Strategi pemasaran pun memiliki cabang-cabang strategi, salah satunya adalah strategi penetapan harga. Menetapkan harga untuk semua pembeli merupakan gagasan yang relatif modern yang muncul bersama perkembangan eceran berskala besar pada akhir abad kesembilan belas. ${ }^{2}$ Secara umum harga ditetapkan melalui negosiasi antara pembeli dan penjual.

Harga barang menjadi sesuatu yang sangat penting, karena bila harga barang terlalu mahal dapat mengakibatkan barang menjadi kurang laku, dan sebaliknya bila menjual terlalu murah, keuntungan yang didapat menjadi berkurang. Suatu perusahaan harus mempertimbangkan banyak faktor dalam menentukan kebijakan penetapan harganya, ${ }^{3}$ juga menerapkan metode-metode yang disesuaikan dengan 
keberadaan faktor-faktor tersebut. Di antara metode dari strategi penetapan harga adalah sistem diskon.

Diskon atau obral merupakan kata yang lumrah ditemukan. Pada momentum tertentu, seperti menjelang peringatan hari raya, banyak swalayan, toko dan penjual barang retail lainnya berlomba-lomba memberikan diskon. Ada hipotesa yang menyatakan bahwa penjual telah menaikkan harga sebesar nilai yang didiskon itu terlebih dahulu baru kemudian mematok diskon lagi. Konsep ini disebut diskon psikologikal. Bila dicermati, kualitas harga barang memang sesuai dengan harga yang diberikan sesudah didiskon. Pada penelitian marketing di Jerman tahun 2004 lalu yang mencoba menganalisis hubungan antara reaksi sinyal otak terhadap suatu produk/promosinya, ditemukan bahwa ternyata otak akan bereaksi (sinyal menguat pada area tertentu) ketika melihat potongan harga pada suatu barang. ${ }^{4}$

Hasil penelitian tersebut menyimpulkan bahwa otak bereaksi seketika (memberikan sinyal-sinyal tertentu) terhadap pesan khusus seperti "potongan harga, diskon, sale" dan sejenisnya. Sinyal-sinyal otaklah yang akan mengendalikan seseorang untuk bertindak, dalam hal ini membeli barang yang ditawarkan dengan diskon. Inilah awal mula perkembangan neuromarketing.

Persepsi konsumen tentang harga juga banyak dipengaruhi oleh strategi penetapan harga alternatif seperti neuromarketing. Banyak pelanggan melihat sebuah barang seharga Rp. 3.990 sebagai harga Rp. 3.000, bukan Rp. 4.000. Fakta lain, banyak pembeli barang lebih memilih mengunjungi stand penjualan yang tertulis "Potongan Harga: 15.000 dapat 3" dibanding stand yang tertulis "Harga Rp. 3000 per barang".

Dari strategi marketing tersebut, benar jika dikatakan keputusan belanja seringkali tidak ditentukan oleh hal-hal yang rasional. Strategi neuromarketing yang gencar dilancarkan membuat konsumen seringkali tidak menyadari apakah dirinya dirugikan atau tidak.

Diskon psikologikal merupakan salah satu strategi penetapan harga promosi dan suatu produk dari neuromarketing sebagai salah satu strategi pemasaran yang sering diterapkan di perusahaan-perusahaan ritel baik kecil maupun besar, di Indonesia. Indonesia memiliki lebih dari setengah penduduk yang merupakan masyarakat muslim. Oleh karena itu sebagai strategi pemasaran, sistem diskon psikologikal perlu ditinjau dan dicarikan solusi, apakah sesuai dengan syari'at Islam atau tidak. Demi kemaslahatan keseluruhan umat Islam di dunia dan secara khusus di Indonesia.

\section{Metodologi Penelitian}

Penelitian dilakukan di Carrefour Serang yang berlokasi di Jl. Ahmad Yani No. 196-198 dan memiliki luas sekitar $15.000 \mathrm{~m}^{2}$.

Metode penelitian yang penulis gunakan adalah pendekatan kualitatif interaktif, yaitu studi kasus. Penulis menggunakan metode ini dengan cara mengambil data yang mendalam dari lokasi obyek penelitian dan menyertakan berbagai sumber informasi. 
Data atau informasi yang dikumpulkan dengan cara melakukan wawancara dengan narasumber, yaitu bagian personalia Carrefour Serang dan sepuluh pelanggan Carrefour Serang. Selain itu penulis juga melakukan observasi, yaitu dengan mengamati obyek penelitian berupa metode-metode strategi penetapan harga apa saja yang diaplikasikan di Carrefour. Penulis juga menggunakan metode dokumentasi, dengan cara menulusuri bahan dokumenter seperti data yang tersimpan di website.

Mengenai pengolahan data, penulis menggunakan analisis kualitatif deskriptif naratif-logis dengan teknik empiris induktif melalui proses pengumpulan data dan pengujian bagian-bagiannya.

\section{Hasil Penelitian}

Dalam menghadapi persaingan, ada beberapa hal yang menjadi perhatian Carrefour Serang untuk memenangkan pasar:

1. Menentukan target pasar. Misalnya menekankan harga murah untuk menjangkau konsumen kelas menengah ke bawah atau memberikan pelayanan dan kualitas produk terbaik untuk menjangkau sasaran pasar menengah ke atas. Dalam hal ini Carrefour menggunakan strategi penetapan harga EDLP (Every Day Low Pricing) atau penetapan harga rendah setiap hari untuk menekankan kontinuitas harga retail pada level antara harga non obral reguler dan harga obral diskon paling besar pesaing retail.

2. Menciptakan loyalitas pelanggan. Misalnya dengan memberikan kartu diskon bagi para member atau mengadakan event promosi setiap akhir pekan. Carrefour telah menerbitkan discount card pada tahun 2011. Keuntungan yang diperoleh oleh para member adalah mendapatkan potongan $5 \%$ pada setiap item berlabel Carrefour dan chasback $15 \%$ pada setiap transaksi di Carrefour yang dapat mengurangi biaya tagihan bulan berikutnya. Selain itu pada setiap perbelanjaan pada kelipatan tertentu akan dipotong Rp. 25.000 serta mendapatkan 1 point pada setiap kelipatan tertentu tersebut dan dapat ditukarkan dengan reward berupa boneka cantik dan lain sebagainya. Di samping itu, Carrefour mengadakan promo mingguan yang diadakan tiap akhir pekan dengan menerbitkan katalog belanja berbentuk Koran 'harga murah' dengan tema berbeda sesuai agenda promosi

3. Memilih lokasi usaha yang strategis. Pemilihan lokasi usaha sangat mempengaruhi tingkat penjualan pada bisnis retail. Misalnya lokasi yang ada di tengah pemukiman warga, bisa didirikan toko kelontong. Sedangkan untuk lokasi usaha yang ada di daerah perkotaan, membuka bisnis retail dengan minimarket atau supermarket adalah lebih sesuai. Saat ini, lokasi Carrefour yang berada di Jalan Ahmad Yani dinilai sangat strategis. Sebab keberadaanya di tengah kota tepat di sebelah kiri barat traffic light Ciceri.

4. Mencantumkan brand pada setiap produk. Penanaman image kepada para konsumen, menjadi cara jitu untuk memasarkan bisnis retail. Seperti mencantumkan logo di setiap label harga produk, atau mencantumkan logo pada interior ruangan. 
5. Memberikan pelayanan prima kepada konsumen. Karena pemasaran bisnis retail lebih mengacu pada konsumen akhir sebagai potensi pasar, maka Carrefour merasa perlu melakukan pendekatan langsung kepada konsumen. Hal paling kecil yang dilakukan adalah melayani konsumen dengan 3S 1A (sambut, senyum, sapa dan antusias) misalnya seperti menyambut konsumen dengan salam dan mengucapkan terimakasih setelah selesai berbelanja. Sehingga konsumen merasa dihargai ketika berbelanja, dan tidak segan untuk datang berbelanja kembali.

Carrefour memperoleh diskon, rabat, insentif, komisi dan bonus barang dari pemasok dengan cara negosiasi. Didukung dengan kekuatan pembelian dalam hal ini kuantitas yang besar, Carrefour memperoleh sejumlah diskon tambahan yang akan menekan harga pokok pembelian.

Alhasil, dengan harga pokok pembelian yang rendah, mampu memberikan keleluasaan kepada Carrefour untuk meyusun harga jual sesuai dengan tingkat keuntungan yang diinginkan dan melakukan penyesuaian terhadap harga jual pesaing.

Persentase gross margin yang rendah akan diterapkan Carrefour untuk produk yang memiliki karakter tingkat perputaran cepat dengan investasi persediaan rendah. Demikian pula sebaliknya. Besarnya persentase gross margin yang diterapkan pada setiap kategori produk berbeda satu sama lain. Persentase gross margin yang relatif rendah biasanya diterapkan terhadap produk yang memiliki karakter brand image kuat dan memiliki tingkat perputaran yang cepat. Sedangkan persentase gross margin yang relatif tinggi biasanya diterapkan Carrefour terhadap produk dengan karakter sebaliknya atau produk yang diolah sendiri di dalam gerai. Persentase gross margin tertinggi diterapkan Carrefour untuk kategori produk bakery dan makanan siap santap (ready to eat), yaitu produk yang diolah sendiri di dalam gerai. Persentase gross margin untuk kedua kategori produk tersebut berkisar antara $30-70 \%$.

\section{Kebijakan Penetapan Harga pada Perusahaan Carrefour Serang Ditinjau} dari Sudut Pandang Islam

Carrefour Serang pada dasarnya adalah franchisee yang melaksanakan seluruh kebijakan yang ditetapkan oleh franchisor-nya yaitu Carrefour Lebak Bulus. Menurut Asosiasi Franchise Indonesia, yang dimaksud dengan franchise (waralaba) adalah suatu sistem pendistribusian kepada pelanggan akhir, di mana pemilik merek (franchisor) memberikan hak kepada individu atau perusahaan untuk melaksanakan bisnis dengan merek, nama, sistem, prosedur dan cara-cara yang telah ditetapkan dalam jangka waktu tertentu dan meliputi area tertentu. ${ }^{5}$ Jadi, Carrefour Serang tidak membuat kebijakan sendiri melainkan melaksanakan kebijakan yang sudah ditetapkan Carrefour di Lebak Bulus. Termasuk di dalamnya kebijakan penetapan harga.

Allah Swt. menetapkan bahwa setiap orang berhak menjual barangnya dengan harga yang ia sukai. ${ }^{6}$ Rasulullah saw. Bersabda:

"Jual beli itu tidak lain hanyalah dengan sama-sama ridha." 
Namun, terdapat rukun dan syarat yang harus dipatuhi dalam penentuan harga pada jual beli agar transaksi bernilai. Instrumen terpenting dalam jual beli adalah harga sehingga harga menjadi tolak ukur keadilan dalam jual beli. Harga yang adil merupakan dambaan bagi penjual maupun pembeli. Harga ini tercipta atas kekuatan penawaran dan permintaan antara penjual dan pembeli tanpa ada unsur paksaan antara pelaku pasar.

Harga harus mencerminkan manfaat bagi pembeli dan penjualnya secara adil, yaitu penjual memperoleh keuntungan yang normal dan pembeli memperoleh manfaat yang setara dengan harga yang dibayarkannya. ${ }^{7}$

Setiap produksi hanya berhak atas imbalan yang sepadan, tidak lebih dan tidak kurang. Dalam surat Al-Muthaffifin ayat 1-3 disebutkan:

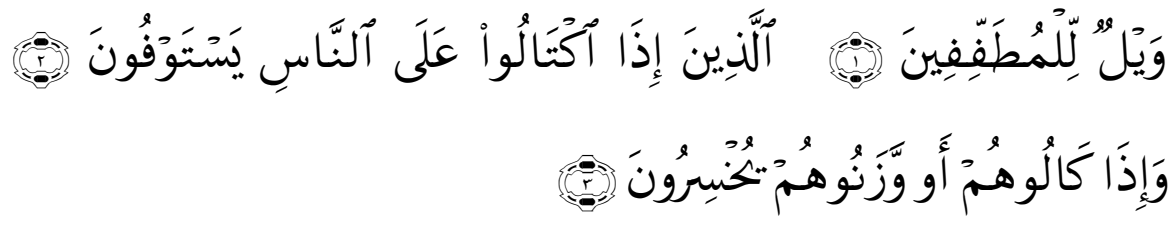

"Kecelakaan besarlah bagi orang-orang yang curang, (yaitu) orang-orang yang apabila menerima takaran dari orang lain mereka minta dipenuhi dan apabila mereka menakar atau menimbang untuk orang lain, mereka mengurangi."

Dan dalam surat An-Najm ayat 39:

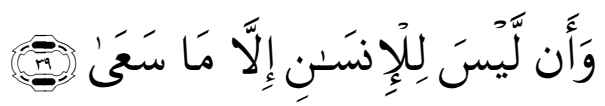

"Dan bahwasanya seorang manusia tiada memperoleh selain apa yang telah diusahakannya."

Pelanggaran terhadap harga pasar, misalnya penetapan harga dengan cara dan karena alasan yang tidak tepat, merupakan suatu ketidakadilan yang akan dituntut pertanggungjawabannya di hadapan Allah Swt. Sebaliknya, dinyatakan bahwa penjual yang menjual dagangannya dengan harga pasar adalah laksana orang yang berjuang di jalan Allah, sementara yang menetapkan sendiri termasuk sebuah perbuatan ingkar kepada Allah. ${ }^{8}$

Oleh karena itu, untuk menciptakan sistem bisnis waralaba yang Islami diperlukan sistem nilai syari'ah sebagai filter moral bisnis yang bertujuan untuk menghindari berbagai penyimpangan moral bisnis. ${ }^{9}$ Filter tersebut adalah komitmen menjauhi tujuh pantangan maghrib:

a. Maisir, segala bentuk spekulasi judi (gambling) yang mematikan sektor ril dan tidak produktif

b. Asusila, praktik usaha yang melanggar kesusilaan dan norma sosial. 
c. Gharar, segala transaksi yang tidak transparan dan tidak jelas sehingga berpotensi merugikan salah satu pihak.

d. Haram, objek transaksi dan proyek usaha yang diharamkan syari'ah.

e. Riba, segala bentuk distorsi mata uang dengan menjadikan mata uang sebagai komoditas dan mengenakan tambahan (bunga) pada transaksi $\mathrm{kredit} / \mathrm{pinjaman} / \mathrm{pertukaran}$ antara barang ribawi sejenis.

f. Ihtikar, penimbunan dan monopoli barang dan jasa untuk mempermainkan harga.

g. Berbahaya, segala transaksi dan usaha yang membahayakan individu maupun masyarakat.

Dalam penetapan harga, Perusahaan Carrefour menerapkan kebijakan Every Day Low Price (EDLP) yang dikombinasikan dengan strategi leader pricing, price bundling, odd pricing, dan price lining.

Strategi EDLP mempunyai tiga manfaat, yaitu:

a. Berkurangnya perang harga. Dengan aplikasi strategi EDLP, perusahaan dapat meminimalisir perang harga dengan sesama peritel. Hal yang mendorong semakin banyak perang harga dalam bisnis ritel adalah bahwa banyak pelanggan yang menunggu dan menunda pembelian sampai sebuah peritel melakukan sale.

b. Berkurangnya iklan. Implementasi strategi EDLP menyebabkan kecendrungan harga stabil di pasaran. Dengan kondisi ini, maka ritel dapat mengurangi frekuensi iklan karena tidak perlu menginformasikan perubahan harga dalam waktu yang terlalu pendek.

c. Berkurangnya kelebihan persediaan dan memperbaiki manajemen persediaan. Implementasi strategi EDLP menyebabkan tingginya frekuensi dan banyak variasi permintaan dengan demikian akan cendrung mengurangi kelebihan persediaan dan memperbaiki manajemen persediaan.

Implikasi strategi EDLP pada Carrefour dapat menarik banyak konsumen karena dilakukan secara terus menerus sehingga menimbulkan image bahwa hargaharga produk di Carrefour relatif murah. Hal ini amat menguntungkan bagi Carrefour mengingat Carrefour menekankan volume penjualan yang tinggi karena laba besar bertumpu pada kuantitas penjualan.

Al-Ghazali tidak menolak kenyataan bahwa mencari keuntungan merupakan motif utama dalam perdagangan. Keuntungan yang sesungguhnya adalah keuntungan yang diperoleh di akhirat kelak. Menurutnya, mengurangi margin keuntungan dengan menjual harga yang lebih murah akan meningkatkan volume penjualan. Dan pada gilirannya akan meningkatkan keuntungan. ${ }^{10}$

Adapun strategi lain yang diterapkan Carrefour di antaranya leader pricing yaitu menjual harga suatu produk di bawah biayanya yang tujuannya bukan untuk meningkatkan penjualan produk bersangkutan, tetapi untuk menarik konsumen supaya datang ke toko dan membeli pula produk-produk lainnya, dan strategi price bundling yaitu strategi pemasaran dua atau lebih produk dalam satu harga paket yang memiliki maksud di samping memikat calon pembeli juga melariskan barang lain yang keadaan pasarnya sedang sepi. Dua strategi ini diterapkan secara kondisional. Diterapkan dalam jangka pendek tertentu agar dapat mempengaruhi konsumen untuk 
membeli barang lain selain merek yang ditawarkan pada jangka waktu tertentu. Jika kedua strategi ini diterapkan secara kontinyu maka akan terjadi persaingan harga yang sengit dan bisa menjadi bumerang bagi perusahaan. Rasulullah saw. bersabda: "Janganlah kamu menjual menyaingi penjualan saudaramu". (HR. Bukhari dari Abdullah bin Umar ra). ${ }^{11}$

The war of price (perang harga) tidak diperkenankan karena bisa menjadi bumerang bagi para penjual. Secara tidak langsung Rasulullah saw. menyuruh kita untuk tidak bersaing di price tetapi bersaing dalam hal lain seperti quality (kualitas), delivery (layanan) dan value added (nilai tambah). ${ }^{12}$

Adapun strategi price lining adalah strategi placing produk menurut klasifikasi harga. Hal ini pun termasuk ke dalam promosi penjualan. Konsumen akan dengan mudah menemukan produk yang diinginkan, baik yang paling murah, sedang ataupun premium.

Etika dalam berpromosi tidak luput dari perhatian Rasulullah saw. Kisah ini mendeskripsikan bahwa Rasulullah saw. telah mengingatkan kepada pendagang tentang pentingnya konteks atau cara dalam melakukan penjualan. Suatu ketika pernah Rasulullah saw. lewat di depan seseorang yang sedang menawarkan baju dagangannya. Orang itu tinggi sedang baju yang ditawarkannya pendek. Kemudian Nabi Muhammad saw. bersabda, "Duduklah! Sesungguhnya kamu menawarkan dengan duduk itu lebih mudah mendatangkan rezeki." (HR. Thusi). ${ }^{13}$

Strategi terakhir adalah odd pricing, yakni penetapan harga ganjil. Maksudnya adalah menetapkan harga tidak pada nominal yang bulat. Misalnya harga sabun mandi diberi label Rp. 2.975, bukan Rp. 3.000. Jika konsumen membayar dengan uang Rp. 5.000 maka uang kembali yang sejatinya harus diterima adalah Rp. 2.025, namun pada kenyataan yang sudah masyarakat umum ketahui bahwa uang Rp. 25 sudah tidak berlaku lagi di Indonesia. Maka uang kembali yang akan si konsumen terima hanyalah Rp. 2.000. Lalu dimana hak konsumen sebesar Rp. 25 ?

Sebenarnya, harga sabun mandi tersebut adalah Rp. 3.000, namun pihak perusahaan mencoba strategi yang dapat mempengaruhi psikologi konsumen. Walau secara logis konsumen menyadari bahwa ia akan membayar Rp. 3.000, namun pikiran bawah sadarnya telah terpengaruh, karena teori psikologis telah menyatakan bahwa umumnya masyarakat membaca harga dari kiri ke kanan. Sehingga konsumen yang tidak mempertimbangkan kualitas atau tidak setia pada merek tertentu akan terpengaruh untuk lebih memilih sabun seharga Rp. 2.975 dari pada sabun dengan harga Rp. 3.100, walau hanya selisih Rp. 125. Maka pada praktek strategi ini, perusahaan tidak memberikan informasi yang sempurna kepada konsumen.

Rasulullah saw. telah melarang berbagai transaksi yang terjadi dalam ketidaksempurnaan informasi, misalnya menghalangi transaksi pada harga pasar (talaqi rukhban), mengambil keuntungan tinggi dengan memanfaatkan kebodohan konsumen (ghaban fahisy). ${ }^{14}$

Dalam kitab Bulughul Maram disebutkan: 


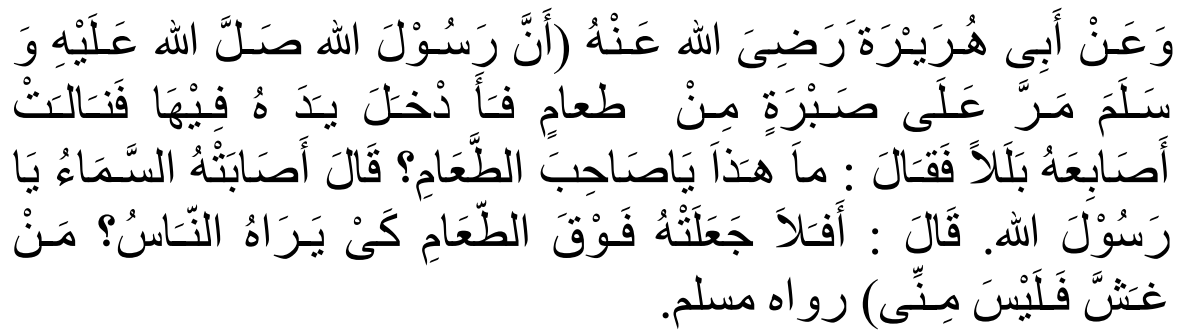

"Dari Abi Hurairah, bahwa Rasulullah saw. pernah melalui satu timbunan dari (biji-biji) makanan, lalu ia masukkan padanya tangannya lalu tangannya kena basah, sabdanya: "Apa ini, hai penjual makanan?"Ia jawab: "Kena hujan ya Rasulullah." Ia bersabda: "Mengapa engkau tidak taruh dia di sebelah atas supaya orang-orang lihat dia? Barangsiapa menipu, bukanlah ia dari (golongan) kita." (HR. Muslim). ${ }^{15}$

Banyak penipuan yang terjadi di pasar akan menimbulkan persaingan tidak sehat. Tentu kerugian akan menimpa semua aspek termasuk penjual, pembeli, barang juga harta yang menjadi tidak berkah. Hal ini akan sangat mengganggu mekanisme pasar.

Beberapa contoh faktor-faktor insidental dan temporer yang mengganggu mekanisme pasar adalah sengaja menimbun (ihtikar), penciptaan permintaan semu (najasy), penipuan kuantitas, kualitas, harga, waktu pengiriman barang (tadlis), kolusi para pedagang untuk membuat harga di atas harga normal (bai' al-hadir lil badi), dan lain sebagainya. ${ }^{16}$

\section{Konsep Neuromarketing dalam Perspektif Islam}

Ruang lingkup neuromarketing sangatlah luas, tidak sekedar hanya menstimulus prospek agar tertarik dengan apa yang seller tawarkan lalu prospek membelinya. Akan tetapi mencakup keseluruhan proses dari promosi, pemasaran hingga bagaimana membuat pelanggan fanatik akan produk atau jasa. Ada tujuh konsep pemasaran menurut neuromarketing, yaitu: ${ }^{17}$

a. Membangun kampanye pemasaran. Langkah pertama strategi ini adalah identifikasi market yang meliputi $4 \mathrm{~W} 1 \mathrm{H}$ (who, where, what, why, how). Who adalah $\mathrm{W}$ pertama yang dibahas. Maksudnya adalah siapa target pasar yang ingin dituju. Misalnya dapat dirinci dengan pembatasan umur, gender, agama, profesi, penghasilan, hobi, status dan pendidikan. Where adalah W kedua. Beberapa hal yang dapat digali adalah lokasi tempat tinggal, lokasi tempat kerja, majalah atau Koran yang dibaca, lokasi sekolah anak, tempat menghabiskan waktu, penginapan yang disukai, mall yang disukai, dll. Dengan mengetahui konsentrasi terbesar, tempat-tempat dan bacaan serta hobi, akan lebih mudah untuk menentukan media yang dipakai untuk promosi. Dari data yang telah didapat dari dua $\mathrm{W}$ pertama, maka akan mudah untuk mengetahui apa yang dipirkan target (what). Dengan mengetahui data singkat dari target, muncul peluang yang baik untuk 
mempengaruhi agar target memakai jasa atau membeli produk seller. Why adalah $\mathrm{W}$ terakhir yang harus dikembangkan. Mengapa mereka memilih seller A atau seller B, sangat tergantung dengan keberhasilan seller dalam mengembangkan 3 W pertama dan memanfaatkannya secara maksimal. Identifikasi yang terakhir adalah How. Yaitu bagaimana menentukan strategi pemasaran yang unik yang akan memposisikan perusahaan dalam memasarkan produk dan jasanya. ${ }^{18}$

b. Mengetahui biaya yang akan dikeluarkan dibanding dengan hasil yang akan diperoleh. Dalam hal ini adalah mengestimasikan biaya yang akan dikeluarkan lalu dibanding dengan estimasi hasil yang akan diperoleh. Untuk menentukan estimasi biaya, diperlukan pengumpulan data misalnya biaya gedung, gaji karyawan, biaya operasional, dan lain-lain.

c. Menyusun kekuatan dan keunikan dari produk dan jasa yang akan dipasarkan. Inti dari penguasaan pasar adalah bagaimana menguasai benak konsumen. Sehingga 'pertempuran' sesungguhnya dalam marketing bukanlah pada perebutan pangsa pasar, tetapi ada pada penanaman persepsi dalam benak konsumen. ${ }^{19}$ Ada sepuluh point yang perlu ditentukan keunikannya oleh marketer agar perusahaan memiliki warna tersendiri di benak konsumen, yaitu: price (harga), quality (kualitas), quantity (kuantitas), range of product (keanekaragaman produk dan jasa), guarantee (jaminan), image (tampilan), trust (kepercayaan), convinience (kenyamanan belanja), place (lokasi) dan gimmick (hadiah). ${ }^{20}$

d. Cara menyusun komunikasi yang tepat. Strategi ini adalah mengenai bagaimana merumuskan iklan yang jitu. Dalam hal ini teori yang dipakai adalah teori $A I D A$ (Attention, Interest, Desire, dan Action) yaitu teori yang sangat sederhana dan sudah biasa digunakan para perumus iklan. ${ }^{21}$ Attention adalah perhatian, yaitu bagaimana menarik perhatian dengan cara yang tepat dan cepat di berbagai kerumunan. Interest adalah ketertarikan, yaitu apa saja hal-hal yang membuat ketertarikan pasar untuk memperhatikan iklan anda lebih lanjut. Desire adalah hasrat, yaitu apa yang harus ditawarkan sehingga memungkinkan permintaan pasar akan menjadi semakin lebih tinggi. Action adalah tindakan, yaitu menginformasikan dimana produk atau jasa yang ditawarkan dapat dibeli.

e. Mencari pelanggan baru. Untuk menumbuhkan banyak pelanggan baru, harus memperbanyak strategi pemasaran dalam memasarkan produk dan jasa. Jadi apabila satu strategi kurang efektif, maka masih bisa memakai strategi lain yang bisa memperkuat posisi marketer.

f. Mempertahankan dan meningkatkan kesetiaan pelanggan. Tidak ada gunanya jika menambah pelanggan baru, membuka pasar baru tanpa dapat menjaganya. Banyak cara yang dapat digunakan untuk menjaga pelanggan, di antaranya adalah selalu memberi lebih dari pada yang sudah dijanjikan, menyusun jadwal dalam menghubungi pelanggan, kualitas terbaik adalah pemasaran terbaik bagi pelanggan setia, memberikan informasi mengenai produk atau jasa terbaru, menawarkan kontrak kerjasama untuk jangka waktu tertentu untuk manfaat yang lebih banyak. 
g. Evaluasi. Evaluasi harus dilakukan secara konsisten dan berkala sehingga hasil yang lebih baik akan terus dapat tercapai.

Keseluruhan konsep di atas sesungguhnya pernah dipraktekkan oleh pebisnis ulung nomor wahid yaitu Nabi Muhammad saw. pada abad 6 Masehi.

Pada usia dua puluh lima tahun, beliau mulai berbisnis hingga ke mancanegara. Akhlaknya yang mulia dan terpuji serta jujur dalam berbisnis, membuat namanya terkenal di seantero jazirah Arab. Nabi saw. sudah menciptakan brand image sebelum menjadi seorang Nabi. Bahwa beliau adalah seorang yang berakhlak mulia, jujur dan terpercaya. Saat image orang sudah terbangun dengan positif, maka pada saat berbisnis pun orang akan percaya. Oleh karena itu, beliau menjadi seorang pebisnis yang suksesnya belum pernah dicapai manusia sesudahnya.

Marketing Nabi Muhammad saw. terkonsep ke dalam tiga paradigma Syari'ah Marketing: ${ }^{22}$

a. Sharia marketing strategy untuk memenangkan mindshare.

b. Sharia marketing tactic untuk memenangkan market-share.

c. Sharia marketing value untuk memenangkan heart-share.

Dilengkapi lagi dengan satu strategi lagi yang merupakan payung dari bentuk strategi lainnya, yaitu:

d. Spiritual marketing untuk memenangkan sustainable keberhasilan hidup perusahaan yang akan membentuk image-holistic share marketing.

\section{a. Strategi pemasaran syari'ah untuk memenangkan mindshare}

Strategi ini mencakup proses segmentasi, targetting dan positioning. Segmentasi adalah cara membagi pasar berdasarkan variabel-variabel tertentu seperti geografi, demografi, demografi, psikologi, perilaku dan pada akhirnya ke variabel terkecil, yaitu individu. ${ }^{23}$ Targetting adalah proses pemilihan target dan mencocokkan reaksi pasar dengan kebutuhan dasar, kemampuan daya beli dan keterbatasan yang dimiliki. ${ }^{24}$ Positioning adalah bagaimana menempatkan produk ke dalam benak konsumen secara luas.

Segmentasi dan targetting dilakukan Nabi Muhammad saw. tatkala ia berdagang antar negara ke Syam, Yaman dan Bahrain. ${ }^{25}$

Identifikasi market pada konsep neuromarketing yang telah dijelaskan di atas, merupakan segmentasi terkecil yang dilakukan, yaitu individual segmentation. Rasulullah saw. pun pernah melakukan individual segmentation. Seorang Nabi Muhammad saw. telah melakukan segmentasi pasar yang akan menjadi tujuan perdagangannya berdasarkan faktor georafis, demografis dan psikologis. Namun perbedaannya, sebelum Nabi saw melakukan segmentasi, ia terlebih dahulu melakukan pengenalan market, karena sebelum memulai usaha perdagangan, Nabi saw. telah melakukan beberapa perlawatan ke Bahrain di bagian timur Semenanjung Arabia dan memperhatikan budaya hidup masyarakat di sana, sehingga mendapatkan detail konsumen yang diperlukan untuk melakukan proses segmentasi. Pada akhirnya, Nabi saw. dapat memasuki semua segmen yang ada, yang terdiri dari berbagai 
tingkatan usia, status sosial dan kebiasaan. Jadi, target Nabi Muhammad saw. mencakup semua segmen pasar.

Adapun positioning Nabi Muhammad saw. yang sangat mengesankan dan tidak terlupakan oleh pelanggan melekat pada diri pribadi Muhammad sendiri. Reputasi Nabi Muhammad saw. sebagai pedagang yang jujur dan terpercaya telah terbina dengan baik sejak usia muda. Positioning itulah yang secara terus menerus ditanamkan oleh Nabi saw. sehingga mengakar dengan baik dalam benak para pengusaha.

\section{b. Sharia marketing tactic untuk memenangkan market-share.}

Strategi ini mencakup diferensiasi, bauran pemasaran dan selling. Jika konsep pemasaran neuromarketing memiliki istilah Unique Selling Proposition (USP) dengan sepuluh point-nya yang harus ditentukan sendiri keunikannya, maka marketing syari'ah mengenal istilah diferensiasi. Diferensiasi adalah bagaimana caranya agar berbeda dengan produk atau perusahaan lain.

Cara berdagang Nabi Muhammad berbeda dengan cara konvensional para pedagang Arab. Beliau telah mempelopori suatu Radical Marketing. ${ }^{26}$ Dua ciri utama pemasaran radikal adalah:

1) Mempunyai ikatan-ikatan yang sangat intim dengan target market tertentu dengan tujuan untuk menciptakan sebuah komunitas pelanggan dan mengetahui apa yang sebenarnya diinginkan oleh konsumen.

Muhammad saw. bersabda, "Siapa yang ingin rezekinya dilapangkan Allah atau hingin usianya dipanjangkan, maka hendaklah ia menyambungkan silaturahmi." (HR. Muslim, dari Anas bin Malik ra).

2) Fokus pada pertumbuhan dan ekspansi dari pada upaya pengambilan keuntungan. Dalam berdagang, Nabi Muhammad saw. tidak hanya fokus di kota Mekkah saja tetapi melakukan ekspor sampai ke negeri Syam seperti Palestina, Syria, Libanon dan Yordania. Beliau menganjurkan untuk selalu bermurah hati, menjauhi sumpah yang berlebihan untuk mempromosikan, tidak menyaingi harga jual orang lain (perang harga) dan tidak memotong jalur distribusi.

Dari akhlaknya yang mulia, Rasulullah secara tidak langsung telah menggagas konsep cerdas yang tidak pernah ada sebelumnya dan hingga saat ini belum ada yang bisa sesempurna beliau. Nabi Muhammad saw. telah menjadi Master Brand sebagai pebisnis muda yang jujur hingga dijuluki Al-Amin. Dr. Walter Doyle Staples mengatakan "successful human relations is really the art of making other people feel good about themselves". ${ }^{27}$

Rasulullah saw. pun melakukan bauran pemasaran atau marketing mix. Ada empat konsep bauran pemasaran yaitu product, promotion, price dan place. Jika konsep neuromarketing menggunakan teori AIDA dalam promosi, maka dahulu yang menjadi keunikan Rasulullah saw dalam promosi adalah tidak pernah melebihlebihkan produk dengan maksud untuk memikat pembeli. Beliau pun tidak pernah 
melakukan sumpah untuk melariskan barang dagangannya, apalagi sumpah berlebihan.

Dalam hal selling, Nabi Muhammad saw selalu memberikan kemudahan dalam bertransaksi. Beliau bersabda, "Pedagang yang baik adalah pedagang yang mudah dalam membeli dan mudah dalam menjual." (HR. Bukhari dari Jabir ra). ${ }^{28}$

\section{c. Sharia marketing value untuk memenangkan heart-share}

Strategi ini meliputi branding, processing, service. Brand adalah yang dapat membedakan dari produk atau jasa yang lain dalam kategori yang sama. Sebuah merek adalah kekuatan. Process merupakan penganalisaan peluang pasar, pengembangan strategi marketing, perencanaan langkah-langkah marketing yang akan dilakukan dan memaksimalkan usaha marketing. Sedang service adalah pelayanan yang merupakan dasar dari setiap bisnis.

Menurut Hermawan Kertajaya, pakar marketing Indonesia, Brand is everything. Menurutnya, brand tidak lain adalah indicator value yang ditawarkan kepada seorang pelanggan. Brand juga menjadi aset yang mampu menciptakan value bagi pelanggan dengan memperkuat kepuasan dan loyalitas mereka. ${ }^{29}$

Dalam hal branding, Nabi Muhammad saw. sendiri telah mencetak personal branding yang kuat sebagai pengusaha yang profesional dan jujur. Dengan keluhuran budi pekertinya, khususnya dalam hal bisnis, hal ini tentu terus tertanam dalam benak para relasi juga konsumen sehingga tanpa menerapkan strategi lain pun sebenarnya Nabi saw dapat mempertahankan dan meningkatkan loyalitas pelanggan, terlebih lagi dengan aplikasi prosessing Nabi saw. yang akurat dan service-nya yang totalitas terhadap konsumen.

Abdullah ibn Abdul Hamzah mengatakan, "Aku telah membeli sesuatu dari Muhammad sebelum beliau menerima tugas kenabian dan karena masih ada suatu urusan dengannya maka aku menjanjikan untuk mengantarkan padanya tetapi aku lupa. Ketika teringat tiga hari kemudian, akupun pergi ke tempat tersebut dan menemukan Muhammad saw. masih berada di sana." Beliau bersabda, "Engkau telah membuatku resah, aku berada di sini selama tiga hari menunggumu." (HR. Abu Daud)

\section{d. Spiritual marketing untuk memenangkan sustainable keberhasilan hidup perusahaan yang akan membentuk image-holistic share marketing.}

Pada tahap ini, Muhammad tidak hanya mampu memenangkan heartshare dari konsumen tetapi lebih jauh telah memenangkan shoulshare. Beliau tidak hanya mampu menciptakan pelanggan yang loyal tetapi juga mampu menciptakan pelanggan yang percaya dengan menggunakan formula kejujuran, keikhlasan, silaturahmi dan bermurah hati yang menjadi inti dari seluruh kegiatan marketing yang dilakukan oleh Nabi saw. ${ }^{30}$

Selanjutnya ada enam kunci utama untuk melakukan promosi berbasis neuromarketing, yaitu egocentric, contrast, mudah dimengerti, gunakan cerita, gunakan visual dan mencampurkan emosi ke dalam pesan. Fungsi promosi adalah untuk 
menyampaikan informasi yang benar kepada target termasuk kelebihan dan kekurangan serta manfaat barang atau jasa yang ditawarkan tanpa melebih-lebihkan dan mengurangi informasi, serta mengajak target untuk membeli barang atau memakai jasa yang ditawarkan.

Rasulullah saw. bersabda: "Dua orang yang berjual beli, masing-masing mempunyai hak pilih (untuk meneruskan jual beli atau tidak) selama keduanya masih belum berpisah. Jika keduanya berlaku jujur dan berterus terang (menjelaskan keadaan barang yang diperjualbelikan), maka keduanya mendapat berkat dengan jual beli mereka tetapi jika mereka berdusta dan menyembunyikan cacat, hilanglah berkat jual beli mereka." (HR. Muslim dari Hakim bin Hizam ra).

Jadi, selama informasi yang diberikan sesuai dengan keadaan objek sebenarnya, maka kejujuran yang diusung itulah yang memberikan keuntungan berupa keberkahan dalam bisnis.

\section{Tinjauan Hukum Islam Terhadap Diskon Psikologikal}

Rasulullah saw. pernah ditanya: "Mata pencaharian apakah yang paling baik, ya Rasulullah?" Jawab beliau: "Ialah seseorang yang bekerja dengan tangannya sendiri dan setiap jual beli yang bersih." (HR. Bazzaar). ${ }^{31}$

Lalu bagaimanakah jual beli yang bersih? Secara global akad jual beli harus terhindar dari enam macam 'aib: ${ }^{32}$

a. Ketidakjelasan (jahalah)

b. Pemaksaan (al-ikrah)

c. Pembatasan dengan waktu (at-tauqit)

d. Penipuan (gharar)

e. Kemudaratan (dharar)

f. Syarat-syarat yang merusak

Seperti yang telah dijelaskan bahwa mekanisme diskon psikologikal adalah harga semula dinaikkan terlebih dahulu lalu didiskon. Walaupun mungkin ada diskon, namun relatif kecil. Diskon besar yang diusung hanyalah sebagai pemanis untuk memberikan efek psikologis bagi konsumen. Ini dinamakan permainan psikologis. Contohnya, ada dua jenis sepatu. A yang didiskon dan B yang tidak. Sepatu tanpa diskon berharga rata-rata Rp. 500.000. Sepatu dengan diskon, tertulis 50\% OFF, memiliki harga gross Rp. 900.000. Maka harga netnya sepatu yang didiskon adalah Rp. 450.000. Ternyata selisih harga sebenarnya antara A dan B hanyalah Rp. 50.000. Terkadang orang lebih merasa puas membeli barang seharga 1 juta misalnya dengan diskon $20 \%$ daripada barang tanpa diskon senilai Rp. 800.000. Padahal nominal akhirnya adalah sama.

Secara psikologis, setidaknya ada beberapa peran diskon bagi konsumen:

a. Feel good factor. Mendapat harga lebih murah itu sungguh menyenangkan. Perasaan "nyaman" inilah yang membuat konsumen selalu tergiur dengan kata diskon. Ada semacam rasa "kemenangan" saat mendapatkan diskon.

b. Opportunity loss effect. Jika seseorang membeli barang yang dipromosikan dengan harga 1000 saat ini, sedangkan besok harga menjadi 1200, maka ada 
opportunity loss yang hilang sebesar 200. Perhitungan "beli sekarang mumpung murah" ini akan membuat orang merasa aji mumpung dan menjadi alasan untuk membeli.

c. Sense of urgency. "Hari Senin, harga naik". Salah satu bunyi warning iklan property di televisi. Kondisi ini memicu rasa takut kehilangan di dalam otak. Jadi ada time limit-nya. Jika diskon diberikan tanpa batasan, maka konsumen akan menanggapinya secara biasa saja.

Kombinasi feel good factor, opportunity loss effect, dan sense of urgency inilah yang mendorong orang untuk terus berbelanja. Namun, tidak semua diskon adalah manipulasi. Ada perusahaan yang memang ingin memanjakan pelanggan dengan memberikan diskon pada jangka waktu tertentu atau memberikan diskon sebagai hadiah bagi pelanggan yang loyal yang memenuhi persyaratan tertentu. Tetapi ada saja perusahaan yang menghalalkan segala cara dengan menyalahgunakan konsep neuromarketing untuk mempengaruhi konsumen agar memilih produknya.

Dari tanggapan sepuluh pelanggan pasar modern, kesan yang penulis peroleh adalah pada awalnya masyarakat merasa diskon besar sangatlah tidak rasional. Masyarakat menilai bahwa ada yang tidak beres dengan penetapan harga diskon. Sehingga masyarakat mulai penasaran dan membandingkan harga produk dari swalayan ini ke swalayan ini, atau membandingkan harga produk pada saat diskon dengan harga normal non diskon. Lalu benang merah pun diambil. Ternyata diskon yang digembar-gemborkan swalayan hanyalah tipuan belaka. Harga produk yang dipasarkan sebenarnya telah dinaikkan terlebih dahulu lalu diberi label diskon. Seorang pelanggan beranggapan bahwa hal itu adalah strategi marketing dan menurutnya itu adalah sah, tinggal bagaimana para konsumen menyikapi secara cerdas. ${ }^{33}$ Seorang pelanggan yang lebih ekstrim lagi, menyebutkan bahwa pedagang memanfaatkan sifat konsumtif dan kebodohan masyarakat. Menurutnya, program diskon seperti itu biasanya hanya pada barang-barang dengan brand yang biasa-biasa saja. Tujuan para peritel adalah untuk menjual produk mereka lebih banyak di harihari tertentu dengan memanfatkan kepanikan masyarakat dan tentu saja untuk penghabisan stok. ${ }^{34}$

Hal ini menunjukkan bahwa konsep neuromarketing belum diterima sepenuhnya oleh semua kalangan, walau konsep-konsep tertentu ada di jalur yang tidak menyalahi aturan.

Pada UU No. 8 Tahun 1999 tentang Hukum Perlindungan Konsumen, dinyatakan bahwa konsumen memiliki hak untuk memilih dan mendapatkan barang dan/atau jasa sesuai dengan nilai tukar dan kondisi serta jaminan yang dijanjikan (Pasal 4 ayat b) dan hak atas informasi yang benar, jelas, dan jujur mengenai kondisi dan jaminan barang dan/atau jasa (Pasal 4 ayat c). ${ }^{35}$

Hak pada pasal 4 ayat $b$ dimaksudkan untuk melindungi konsumen dari kerugian akibat permainan harga secara tidak wajar. Karena dalam keadaan tertentu konsumen dapat saja membayar harga suatu barang yang jauh lebih tinggi daripada kegunaan atau kualitas dan kuantitas barang atau jasa yang diperolehnya. ${ }^{36}$ Sedang pada pasal 4 ayat $\mathrm{c}$, hak atas informasi adalah sangat penting karena tidak 
memadainya informasi yang disampaikan kepada konsumen ini dapat juga merupakan salah satu bentuk cacat produk, yaitu yang dikenal dengan cacat instruksi atau cacat karena informasi yang tidak memadai. ${ }^{37}$

Representasi yang benar terhadap suatu produk, karena salah satu penyebab terjadinya kerugian terhadap konsumen adalah terjadinya misrepresentasi terhadap produk tertentu. Kerugian yang dialami oleh konsumen di Indonesia dalam kaitannya dengan misrepresentasi banyak disebabkan karena tergiur oleh iklan-iklan atau brosur-brosur produk tertentu, sedangkan iklan atau brosur tersebut tidak selamanya memuat informasi yang benar, karena pada umumnya hanya menonjolkan kelebihan produk yang dipromosikan, sebaliknya kelemahan produk tersebut ditutup-tutupi. ${ }^{38}$

Hal ini sejalan dengan kewajiban pelaku usaha pada pasal 7 ayat b, yaitu memberikan informasi yang benar, jelas, dan jujur mengenai kondisi dan jaminan barang dan/atau jasa serta memberi penjelasan penggunaan, perbaikan, dan pemeliharaan. ${ }^{39}$ Juga sejalan dengan perbuatan yang dilarang bagi pelaku usaha pada Hukum Perlindungan Konsumen:

"Pelaku usaha dalam menawarkan barang dan/atau jasa yang ditujukan untuk diperdagangkan dilarang menawarkan, mempromosikan, mengiklankan atau membuat pernyataan yang tidak benar atau menyesatkan mengenai tawaran potongan harga atau hadiah menarik yang ditawarkan." (Pasal 10 ayat d). ${ }^{40}$

"Pelaku usaha dalam hal penjualan yang dilakukan melalui cara obral atau lelang, dilarang mengelabui/menyesatkan konsumen dengan menaikkan harga atau tarif barang dan/atau jasa sebelum melakukan obral." (Pasal 11 ayat f). ${ }^{41}$

Dalam ilmu marketing ada suatu prinsip yang harus dijaga tidak boleh diabaikan yaitu disebut truth in advertising, artinya iklan, reklame, pujian terhadap barang sendiri, tidak boleh berlebihan dan membohongi calon pembeli. Jika iklan mengandung unsur kebohongan apalagi menipu orang, akhirnya akan menimbulkan advertising impact yang negatif. Inilah yang disebut dalam agama dengan istilah najasy atau dapat diistilahkan dengan reklame palsu. ${ }^{42}$ Najasy adalah memuji barang dagangan supaya laku, menawar satu barang dengan harga tinggi supaya orang lain merasa tidak mahal, lalu membeli. Hal ini dilarang oleh agama. Rasulullah saw. Bersabda:

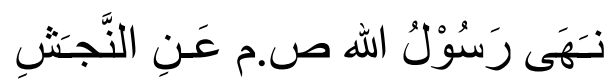

Rasulullah saw. Telah melarang jual beli dengan najasy (Bukhari dan Muslim). ${ }^{43}$

Karena akad muamalah itu di dalamnya wajib sempurna terpenuhi aspek yang bisa menghilangkan perselisihan di antara manusia, maka syari'ah mengharamkan manusia melakukan penipuan di dalam jual beli. Tentang larangan Nabi saw. terhadap jual beli tipuan, para ulama sepakat melarangnya. Tipuan yang dimaksud adalah apabila seseorang menambah harga (tawaran) suatu barang, padahal tidak ada 
keinginan untuk membelinya. Perbuatanya itu dimaksudkan untuk menguntungkan penjual dan merugikan pembeli. ${ }^{44}$

Hukum tipuan, Imam Malik berpendapat bahwa kepada penjual disuruh memilih secara mutlak dan tidak ada keharusan bagi penjual untuk menjual, meskipun kadar tipuan itu telah disusutkan dari laba. Demikian pula halnya dalam masalah kedustaan. Dan ini menurut pendapat Ibnul Qasim.

Sedang menurut Asyhab, tipuan yang berpengaruh terhadap harga, hukumnya sama dengan hukum dusta. ${ }^{45}$ Abu hanifah dan Zumar beralasan kedustaan dalam jual beli itu disamakan dengan barang yang cacat. Maksudnya, jika barang cacat pembeli punya hak khiyar mengembalikan, maka dusta juga demikian. ${ }^{46}$

Selain najasy, tipuan juga bisa disebut tadlis (penipuan) atau bisa juga dengan ghabn (trik). Keduanya sama, yaitu merekayasa sesuatu agar dapat menguntungkan diri sendiri dan mengabaikan orang lain. Syari'ah menjadikan penipuan sebagai sebuah dosa, baik penipuan dilakukan oleh penjual maupun pembeli pada barang maupun harga, semuanya adalah haram. ${ }^{47}$

Seperti yang sudah disebutkan, pengertian tadlis meliputi penipuan kuantitas, kualitas, harga dan waktu pengiriman barang. Sedangkan al-ghabn adalah menjual sesuatu lebih daripada yang sebanding atau membeli sesuatu kurang daripada yang sebanding. ${ }^{48}$ Al-ghabn al-faahisy (trik/tipudaya yang keji) haram secara syarii, karena ditetapkan di dalam hadits shahih adanya tuntutan untuk meninggalkna ghabn dengan tuntutan yang tegas. Diriwayatkan dari Abdullah bin Umar bahwa dua orang laki-laki menyatakan kepada Nabi saw. bahwa ia menipu di dalam jual beli. Lalu Nabi saw. bersabda:

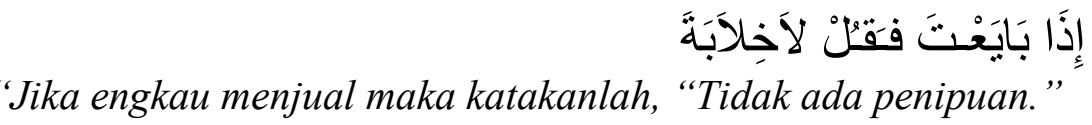

Ibn Majah meriwayatkan bahwa Rasulullah saw. pernah bersabda:

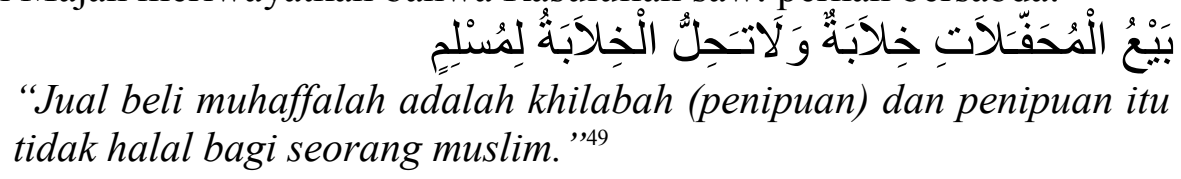

Dalam hadits itu, disabdakan dengan tegas laa tahillu (tidak halal), yaitu diharamkan. Jadi itu menunjukkan bahwa tuntutan untuk meninggalkan penipuan itu merupakan tuntutan yang tegas. Dari sini, alghabn faahisy (trik keji) hukumnya adalah haram.

Hal ini sesuai dengan hadits Nabi saw. yang diriwayatkan oleh Al-Bukhari dan Muslim dari abdullah ibnu Al-Harits dari Hakim inu Hizam bahwa Nabi saw. bersabda: ${ }^{50}$

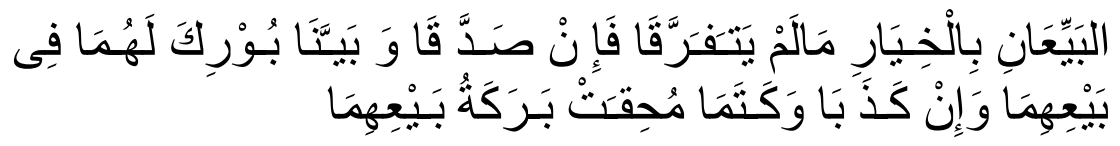


"Penjual dan pembeli keduanya bebas memilih selagi keduanya belum berpisah. Jika mereka jujur maka diberkahilah jual belinya. Tetapi jika mereka menyembunyikan cacat dan dusta maka terhapuslah keberkahan jual beli itu." (HR. Bukhari dan Muslim)

Jika harta sudah tidak berkah maka akan menghadirkan rasa gelisah dalam hidup. Karena jual beli seperti itu bisa berdampak buruk bagi bisnis yang sedang dijalani, misalnya kehilangan kepercayaan dari pelanggan. Rasulullah saw. bersabda, "Sesungguhnya kebenaran membawa ketenangan dan kedustaan menimbulkan keragu-raguan.” (HR. Tirmidzi).

Rasulullah saw tidak pernah mengajarkan sikap dusta, sebab sifat wajibnya adalah shiddiq, amanah, tabligh dan fathonah. Oleh karena itu, seorang pebisnis muslim sangat tidak layak untuk melakukan kecurang-kecurangan dalam transaksi, baik ia mengetahuinya atau tidak.

Etos kerja seorang muslim, dibentuk oleh iman yang menjadi pandangan hidupnya, yang memberinya norma-norma dasar untuk membangun dan membina muamalahnya. Seorang muslim dituntut oleh imannya untuk menjadi orang yang bertakwa dan bermoral amanah jujur, adil, percaya diri, dan terpercaya), berilmu (professional dalam bidangnya), cakap, cerdas, cermat, hemat, rajin, tekun dan bertekad bekerja sebaik mungkin untuk menghasilkan yang terbaik.

Allah Swt. pun akan memberikan reward khusus bagi para pebisnis yang syar'i. Para pedagang jujur, benar dan sesuai dengan ajaran Islam dalam berdagang didekatkan dengan para nabi, para sahabat dan orang-orang yang mati syahid pada hari kiamat. ${ }^{51}$

\section{Penutup}

Berdasarkan hasil pembahasan dan analisa di atas maka penulis dapat mengambil kesimpulan sebagai berikut:

1. Carrefour mempergunakan dua metode penetapan harga, yaitu metode biaya dan permintaan. Adapun strategi yang digunakan untuk meningkatkan lalulintas konsumen dan penjualan barang pelengkap di dalam toko adalah strategi Every day Low Prices (EDLP) yang dikombinasikan dengan strategi leader pricing, price bundling, odd pricing, dan price lining. Bila ditinjau secara syar'i, Carrefour tidak menerapkan nilai-nilai Islami. Hal ini dapat dilihat dari salah satu strateginya ada yang tidak sesuai dengan prinsip-prinsip transaksi Islami.

2. Neuromarketing adalah suatu konsep strategi untuk mempengaruhi alam bawah sadar seseorang untuk membeli/memakai barang/jasa yang ditawarkan. Konsep neuromarketing adalah boleh dalam Islam selama dilakukan dengan transparan dan jujur. Karena asal dari mu'amalah adalah boleh dan landasan jual beli adalah suka sama suka.

3. Diskon psikologikal merupakan strategi penetapan harga yang diadopsi dari konsep neuromarketing. Mekanismenya adalah penjual menaikkan harga terlebih dahulu baru kemudian mematok diskon agar konsumen seolah merasa mendapat 
untung besar. Rasulullah saw. secara tegas melarang ketidaksempurnaan informasi atau penipuan yang diistilahkan dengan ghaban faahisy/tadlis/ khilaabah/najasy dengan menyatakan laa tahillu atau tidak halal atau haram untuk khilaabah bagi seorang muslim dan menyatakan bahwa yang melakukan penipuan bukanlah dari golongannya.

\section{Catatan Akhir:}

Buchari Alma, et. al., Manajemen Bisnis Syari'ah, (Bandung: Penerbit ALFABETA, 2009), hal 69.

2 Philip Kotler dan Kevin Lane Keller, Manajemen Pemasaran, (PT Macanan Jaya Cemerlang, 2008), hal 78.

Ibid, hal 84.

Mianurindah, Neuromarketing, 15 Januari 2009, http://mianurindah.wordpress.com.

Ahmad Wardi Muslich, Fiqih Muamalat, (Jakarta: Amzah, 2010), hal 620.

6 Yusuf As-Sabatin, Bisnis Islami, (Bogor: Al-Azhar Press, 2011), hal 292.

7 Pusat Pengkajian dan Pengembangan Ekonomi Islam (P3EI) Universitas Islam Indonesia Yogyakarta, Ekonomi Islam, (Jakarta: PT RajaGrafindo Persada, 2008), hal 332

Ibid, hal 302.

Adrian Sutedi, Hukum waralaba, (Bogor: Ghalia Indonesia, 2008), hal 42.

10 Pusat Pengkajian, op.cit, hal 306.

11 Thorik Gunara, Marketing Muhammad, Bandung: MadaniA Prima, 2007, hal 62.

2 Ibid, hal 63.

3 Ibid, hal 62.

14 Pusat Pengkajian, op.cit, hal 330.

15 Ibnu Hajar Al-Asqalany, Bulughul maram, (Semarang: Karya Thoha Putra), hal 173.

16 Pusat Pengkajian, loc.cit.

17 Gendro Salim, Neuromarketing, (Jakarta: Sinergi Media, 2010), hal 20.

18 Ibid, hal 32.

19 Thorik Gunara, op.cit, hal 11.

${ }^{20}$ Gendro Salim, op.cit, hal 42.

21 Ibid, hal 57.

22 Buchari Alma, op.cit, hal 263.

23 Thorik Gunara, op.cit, hal 12.

24 Ibid, hal 18.

25 Buchari Alma,op.cit, hal 267.

26 Thorik Gunara, op.cit, hal 46.

27 Abdul Wahid Al-Faizin, et.al, Tafsir Ekonomi Kontemporer, (Jakarta: Madani Publishing House, 2010), hal 270.

28 Thorik Gunara, op.cit, hal 71.

29 Abdul Wahid Al-Faizin, op.cit, hal 268.

30 Thorik Gunara, op.cit, hal 94.

31 Buchari Alma, op.cit, hal 13.

2 Ahmad Wardi Muslich, op.cit, hal 190.

33 Heru Dj., diwawancarai oleh Siti Aisyah Youtefani, Fenomena Diskon, Serang, Maret, 2012.

34 Wandy, diwawancarai oleh Siti Aisyah Youtefani, Fenomena Diskon, Serang, Maret, 2012.

35 Ade Maman Suherman, Aspek Hukum dalam Ekonomi Global, (Bogor: Penerbit Ghalia Indonesia, 2005), hal 100. 
36 Ahmadi Miru, et.al, Hukum Perlindungan Konsumen, (Jakarta: PT RajaGrafindo Persada, 2004), hal 45.

37 Ibid, hal 41.

38 Ibid, hal 55.

39 Ade Maman Suherman, op.cit, hal 102.

40 Ahmadi Miru, op.cit, hal 92.

41 Ibid, hal 93.

42 Buchari Alma, op.cit, hal 149.

43 Hendi Suhendi, Fiqh Muamalah, (Jakarta: PT RajaGrafindo Persada, 2008), hal 82.

44 Ibn Rusyd, Bidayatul Mujtahid Analisa Fiqih Para Mujtahid, jilid 2, (Jakarta: Pustaka Amani, 2007), hal 789.

45 Ibn Rusyd, op.cit, jilid 3, hal 51.

46 Ibid, hal 50.

47 Yusuf As-Sabatin, op.cit, hal 260.

48 Ibid, hal 257.

49 Ibid, hal 258.

50 Ahmad wardi Muslich, op.cit, hal 185.

51 Hendi Suhendi, op.cit, hal 85. 


\section{DAFTAR PUSTAKA}

Al-Faizin, Abdul Wahid, et.al, Tafsir Ekonomi Kontemporer, Jakarta: Madani Publishing House, 2010.

Alma, Buchari, et.al., Manajemen Bisnis Syari'ah, Bandung: Penerbit Alfabeta, 2009.

Al-Asqalany, Ibnu Hajar, Bulughul maram, Semarang: Karya Thoha Putra.

As-Sabatin, Yusuf, Bisnis Islami, Bogor: Al-Azhar Press, 2011.

Gunara, Thorik, Marketing Muhammad, Bandung: Madania Prima, 2007.

Kotler, Philip, dan Kevin Lane Keller, Manajemen Pemasaran, PT. Macanan Jaya Cemerlang, 2008.

Mianurindah, Neuromarketing, 15 Januari 2009, http://mianurindah.wordpress.com.

Miru, Ahmadi, et.al, Hukum Perlindungan Konsumen, Jakarta: PT RajaGrafindo Persada, 2004.

Muslich, Ahmad Wardi, Fiqih Muamalat, Jakarta: Amzah, 2010.

Pusat Pengkajian dan Pengembangan Ekonomi Islam (P3EI) Universitas Islam Indonesia Yogyakarta, Ekonomi Islam, Jakarta: PT RajaGrafindo Persada, 2008 .

Rusyd, Ibn, Bidayatul Mujtahid Analisa Fiqih Para Mujtahid, jilid 2, Jakarta: Pustaka Amani, 2007.

Salim, Gendro, Neuromarketing, Jakarta: Sinergi Media, 2010.

Suhendi, Hendi, Fiqh Muamalah, Jakarta: PT RajaGrafindo Persada, 2008.

Suherman, Ade Maman, Aspek Hukum dalam Ekonomi Global, Bogor: Penerbit Ghalia Indonesia, 2005.

Sutedi, Adrian, Hukum Waralaba, Bogor: Ghalia Indonesia, 2008. 
Siti Aisyah Youtefani, alumni Fakultas Syari'ah dan Ekonomi Islam IAIN Sultan Maulana Hasanuddin Banten. 